\section{Stanovskyi 0. Abu Shena 0., Toropenko A., Daderko 0.}

\title{
DEVELOPMENT OF A SYMBOLIC IMAGE OF BUILDING STRUCTURE IN CAD
}

Показано, що автоматизоване будівельне проектування постійно потребує відновлення моделі споруди. Ця модель повинна відбивати не тільки первинне технічне завдання на будівлю, але й виявлені під час проектування зміни та події в турбулентному внутрішньому та зовнішньому оточуючому майбутне будівництво середовищі. Запропоновано модель будівельної споруди у вигляді символьного образу - комплексної генетичної хромосоми та метод підтримки адекватності між останнім та змінним середовищем.

Ключові слова: будівельне проектування, відновлення моделі, турбулентне середовище, символьний образ, технічна спадковість.

\section{Introduction}

The model of the future object is the main subject of labor in any design, especially in the automated. From the model (technical task), the design process begins and the model (the finished project) - ends. From the adequacy and «convenience» of such models all consumer characteristics and social attractiveness depend not only on the process of creating a description of new complex objects, but also on the operational reliability of the latter, and, finally, their innovative potential and competitiveness in global markets.

At the same time, it is natural that in designing these models constantly change, adapting to the corresponding technological stages of the latter:

- pre-project studies;

- development of project documentation;

- development of working documentation;

- Process types: selection, calculations, optimization, drawing, coordination, etc.

But the changes in the models are not only due to technological adaptation. It is possible to single out the following objects (first of all, in the construction industry), in which the models already under the design are forced to change also under the influence of the external and internal environment surrounding the construction.

The latter has such impact on the design of the future building that from one technical task can turn out quite different projects (and, accordingly, different buildings). These projects have individual properties, caused, for example, by technical heredity from previous and neighboring construction sites, terrain relief, state of access roads, external communications.

Thus, it can be argued that CAD in construction requires universal for all stages of designing models that are relatively easy to adapt to these stages and the turbulent environment of a particular building.

In this work, symbolic branched binary chromosomes are considered as such models, which have proved themselves in the framework of genetic optimization algorithms.

\section{The object of research and its technological audit}

The object of the research is the processes of automated design of the construction or reconstruction of complex building structures under the conditions of individual restrictions on each structure - the technical heredity caused by the internal and external environment surrounding the construction.

Technological audit is a way to diagnose the innovative CAD subsystem in construction, and it allows to obtain the characteristic of innovative potential when creating new and reconstructing existing building structures. Conducting a technological audit gives the project company the opportunity to formulate a strategy for making a profit based on the results of innovation activities. It is assumed that the developer uses the results of innovation directly in the design process, releasing new construction projects using the created design innovations.

The procedure for assessing the commercial potential of the innovation idea was carried out according to an algorithm consisting of seven consecutive steps [1]:

- conducting preliminary analysis;

- search for analogues;

- verification of the technical feasibility of an innovative idea;

- product identification (design result) for comparison with analogues;

- determination of market advantages of the created product;

- practical feasibility of the innovative idea.

The conducted studies confirmed the high commercial potential of the innovative idea: the use of new models as a symbolic image of building objects.

\section{The aim and objectives of research}

The aim of research is reducing the time for individual automated design and improving the quality of complex building structures by developing and implementing adaptive models of the design object at all stages of project development. 
To achieve this aim, it is necessary to solve the following tasks.

1. To analyze the technical task and its place in the process of automated individual design of building structures.

2. To develop the principles of construction and adaptation of symbolic models of building structures in the form of branched binary chromosomes.

3. To carry out a practical test of the results of the study to assess their technical and economic advantages over known methods and models.

\section{Research of existing solutions of the problem}

As stated above, all environmental influences on the design process in construction can be seen as a legacy inherited from the current project from previous and parallel ones, performed for the same technical task, which plays the role of constraints. The problem of heredity in designing has always been complex and ambiguous [2, 3]. After all, on the one hand, while supporting standardization (which in this sense is synonymous with heredity), in some cases, we reduce the cost of designing, manufacturing and operating complex systems. On the other hand, we certainly restrain scientific and technological progress, which is alien to ossification [4, 5]. Unfortunately, heredity is not always «administrative». Most of it is connected with objective reasons, which can even be assumed, but can't be canceled.

The case sometimes comes to the point that when the designer tries to move on to the creative part of his work, he is no longer left with problems of limitations from heredity, what to optimize! That is why the first cars were suspiciously similar to the horse carriages of those times, and the width of the track of some modern trains is equal to the width of the track of the Greek chariots of Alexander the Great [6, 7].

Automation of the processes of designing, developing and implementing specialized CAD systems requires additional methods and models that can not only passively take heredity into account, but also use synergy. The final effect of the interaction of two or more factors, such that the effect of their combined action significantly exceeds the effect of each individual component [8].

Especially, this effect is observed in the construction industry, which, at first glance, is very creative in designing, and on the second - like no other is subject to different types of heredity, especially when reconstructing building structures [9]. Another problem of this design is the time allowed for it by the operating conditions or even the survival of the reconstructed object. To solve this problem, it is necessary to have CAD, built on methods and models designed specifically for accelerating design in unpretentious conditions. Modern automated design of the reconstruction of the building construction, of course, requires new models of the subject area. These models should be equally convenient both in «ordinary» information technologies, and in solving the problems of choice, calculation, optimization and others inherent in the design proper.

One of these kinds of «universal» models, of course, is the symbolic $[10,11]$, the through use of which can go through the whole life cycle of design - from the technical task and trial production and «testing» of the object. The main advantage of such models is that they can be used not only at different design stages to accumulate information on heredity, but also for solving «passing» tasks of object optimization, for example, using genetic algorithms [12].

Thus, the project of the building must contain in its specification all the sections envisaged by the standard: a list of borrowed elements or units, a list of purchased items and a list of newly designed units (Fig. 1).

Accordingly, CAD of such facilities should consist of at least three main subsystems: the subsystem of inheritance (borrowing), the subsystem of selection and planning of purchases, and also the creative subsystem performing new design [13]. Constraints in CAD are individual properties of the area, where it is planned to build a concrete structure, characteristics of external communications and features of the project organization.

In the reconstruction there are additional restrictions on the inheritance of the previous building.

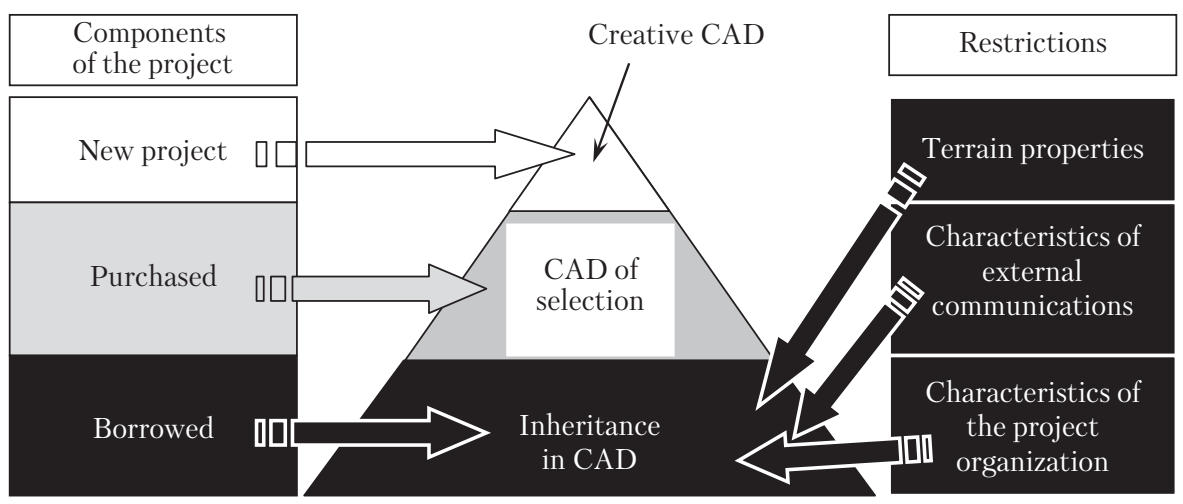

Fig. 1. Sources of inheritance, selection and creativity in the design of building structures

\section{Methods of research}

The basis of individual subsystems of symbolic CAD is the theory of analysis of technical systems, the theory of computer-aided design and the theory of evolutionary optimization using genetic algorithms.

\section{Research results}

6.1. Analysis of the technical task and its place in the process of automated design of building structures. Let's pay attention that at «usual» designing the polyfurcation point of a life cycle of object is at the end of this designing (Fig. 2).

This is due to the fact that in this case both the terms of reference and the project are common for all products, the differences of which from the project are explained by the different conditions for their manufacture and operation. In the construction industry, everything is not so. 
Construction of the same type of construction [14, 15], reengineering of existing building structures [16] and other factors lead to the fact that heredity begins to manifest much earlier. The polyfurcation point is shifted to the output of the technical task (Fig. 2).

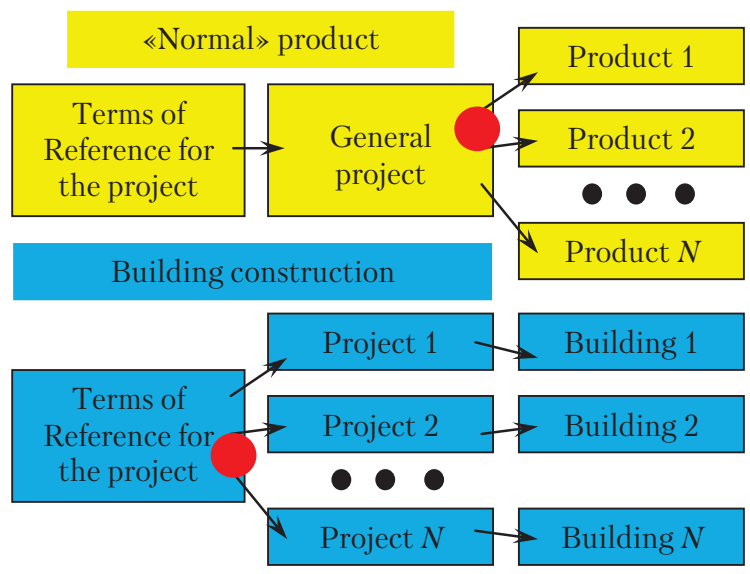

Fig. 2. Polyfurcation points of the life cycle of conventional and building design objects

In CAD building a new subsystem «Correcting the technical task for the project» appears. A new structure of the interaction of the design subsystems with the initial design specification for the project is shown in Fig. 3.

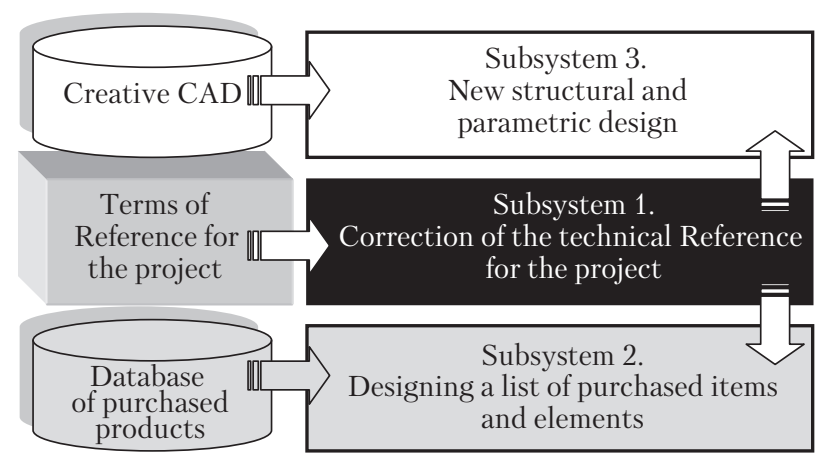

Fig. 3. The place of the technical reference among the main subsystems of building CAD

For example, if in the area where the construction is supposed to be, there is a binding of the external supply of communications, then the place of communication in the building ceases to be settlement, which convenience considerations were not put forward. The adjustment of the technical assignment is carried out continuously throughout the entire design phase.

Thus, when designing a construction there is no single technical task: first, it adapts to the environment.

Next, let's perform the preliminary formalization of the logical space of the building structure [17] and the structural design of the future object and select the original and purchased elements and nodes from the project specification (Fig. 4).

For each element, let's compile a list of parameters and their values (phenomenological image of elements or phenotype), which uniquely determine this element. In the list, generalized, dependent and independent parameters are marked. The latest information follows and is corrected from the adaptive technical assignment.

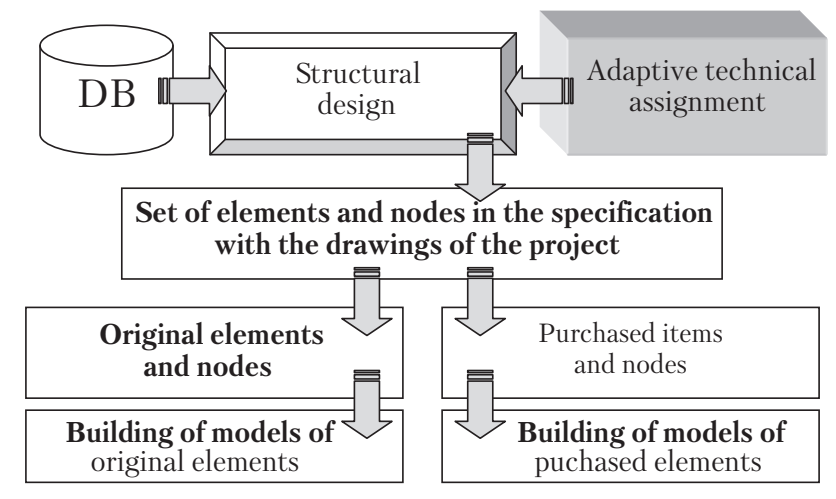

Fig. 4. Isolation of structural elements of the structure

Now, when the place of the technical task and the need for its permanent adaptation to an individual project are clarified, it is possible to proceed to the construction of models of each element.

6.2. Construction and adaptation of symbol models. For this, for each phenomenological image, its genetic image (genotype) is created as it is done in the construction of branched chromosomes in the method of the complex genetic algorithm [18] (Fig. 5).

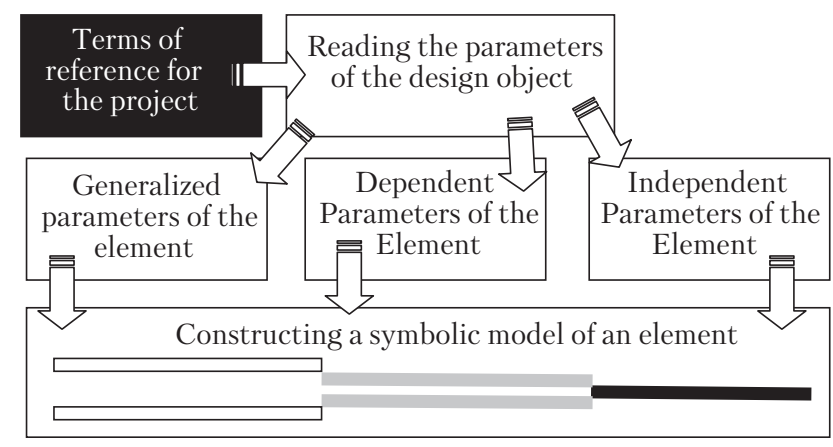

Fig. 5. Construction of symbolic models of purchased and new elements of a building structure

Separation of parameters into generalized, dependent and independent allows constructing complex chromosomes inherent in the complex genetic algorithm for designing elements of objects with internal connections (Fig. 6).

It is shown in Fig. 6 universal complex chromosome reflects not only the phenomenological portrait of the modeled object, but also various types of connectivity between the individual parameters of the latter [19].

Let the symbolic chromosome, shown in Fig. 6, reflects the initial state of modeling the future element of the object, which corresponds to the technical assignment for the latter. Let also at the first stages of the design adaptation of such model to the environment or other limitations, mentioned above, take place.

A method of accounting for such limitations is proposed. In the genetic algorithm, «parents» are selected, which are further bisexual reproduction, and the bisexual mutation consists in replacing 0 by 1 and vice versa. The proposed 
method uses the method of unisex reproduction (Fig. 7), in which the genotype (chromosome) of a single parent is simply cloned.

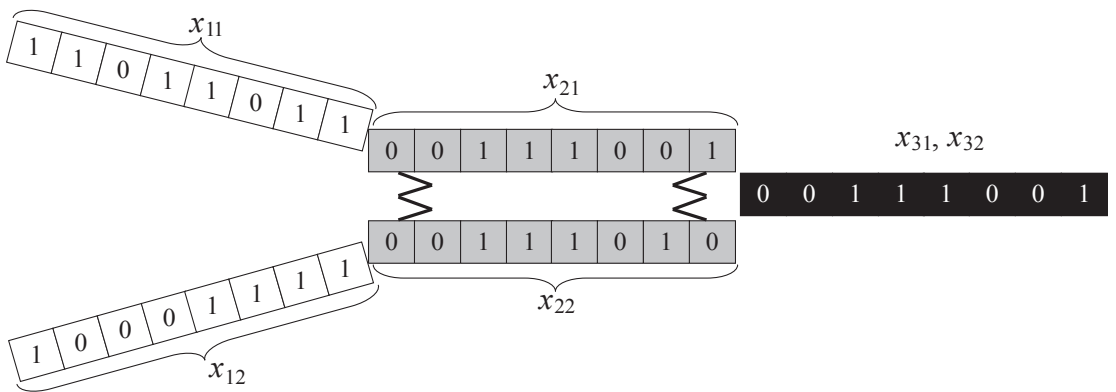

Dependent part

Independent part

Fig. 6. Scheme of the universal complex symbolic model (chromosome or genome) of the object element

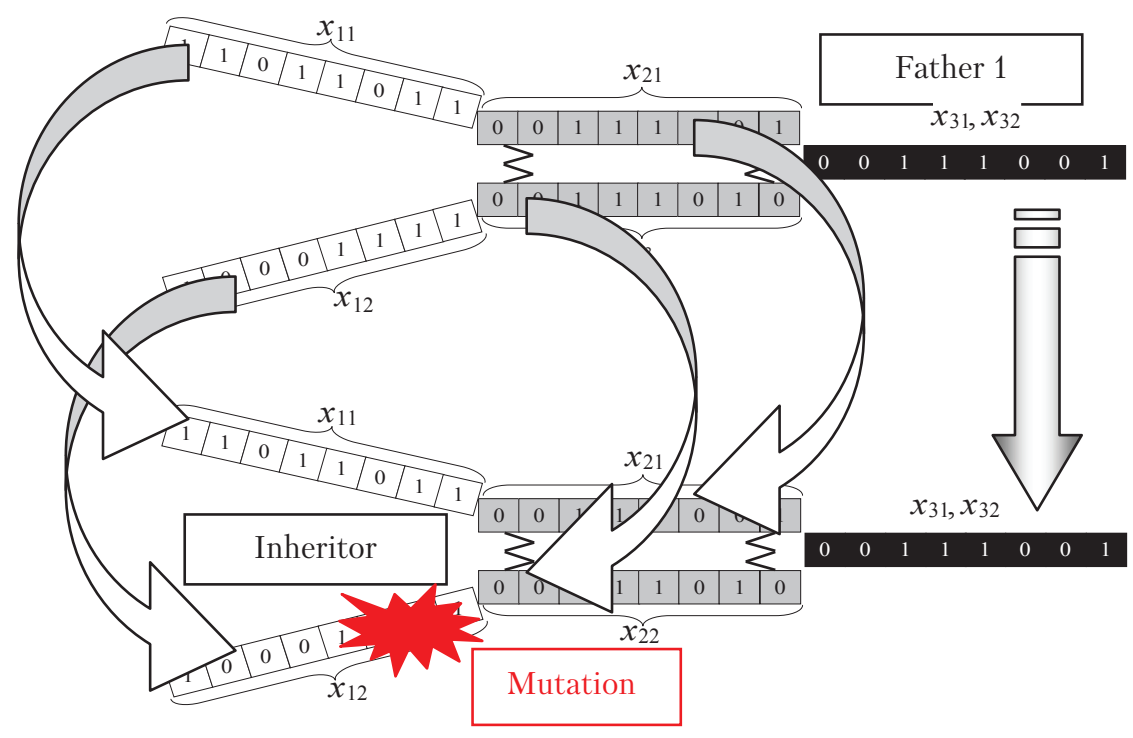

Fig. 7. Scheme of unisex genome reproduction with the formation of a mutant gene
Generalized part

house can't be changed with any optimization of internal network planning. Thus, at this stage, heredity accounting is implemented at the level of symbolic models. The thus created symbolic models (initial and those that constantly mutate under different circumstances) are entered in the corresponding CAD data bank. In the replenishment of this bank can participate information obtained from the Internet: data on purchased products from the sites of producers and sellers, as well as information from relevant catalogs and standards.

It is in this form that symbolic models participate in further operations of choice and original design. For this, output variants of chromosomes are used, but only those genes that are not mutated are subjected to variation from them. For example, Fig. 8 shows the scheme of the algorithm for selecting purchased elements for a certain project.

First, the output «intact» chromosomes are sent for comparison with the data bank. If there are no coincidences, it is possible to vary the values of intact genes of these chromosomes within the given limits. If in this case it is not possible to find a match, the item needs to be moved to the list of newly designed ones.

Optimization processes in CAD are carried out with the help of a complex genetic algorithm, but in its beginning it is no longer necessary to create an array of parental chromosomes, since it already exists and constantly maintains its adaptability to the design object.
This process can be accompanied by same-sex mutations so that the clone that came out may differ substantially in genotype and phenotype from the father. The choice of specific genes that mutate is directly related to the causes and circumstances of inheritance or limitation. At the symbolic level, the same-sex mutation looks like fixation (ossification) of the corresponding gene at the primary level ( 0 or 1$)$ with the prohibition in the future of changing this value to the end of the simulation. When such chromosomes with fixed gene values go, for example, to genetic optimization, the prohibition of changing the value extends to this stage.

An example of such restriction may be the coordinates of the supply of water from the external network. The coordinates of water connection inside the

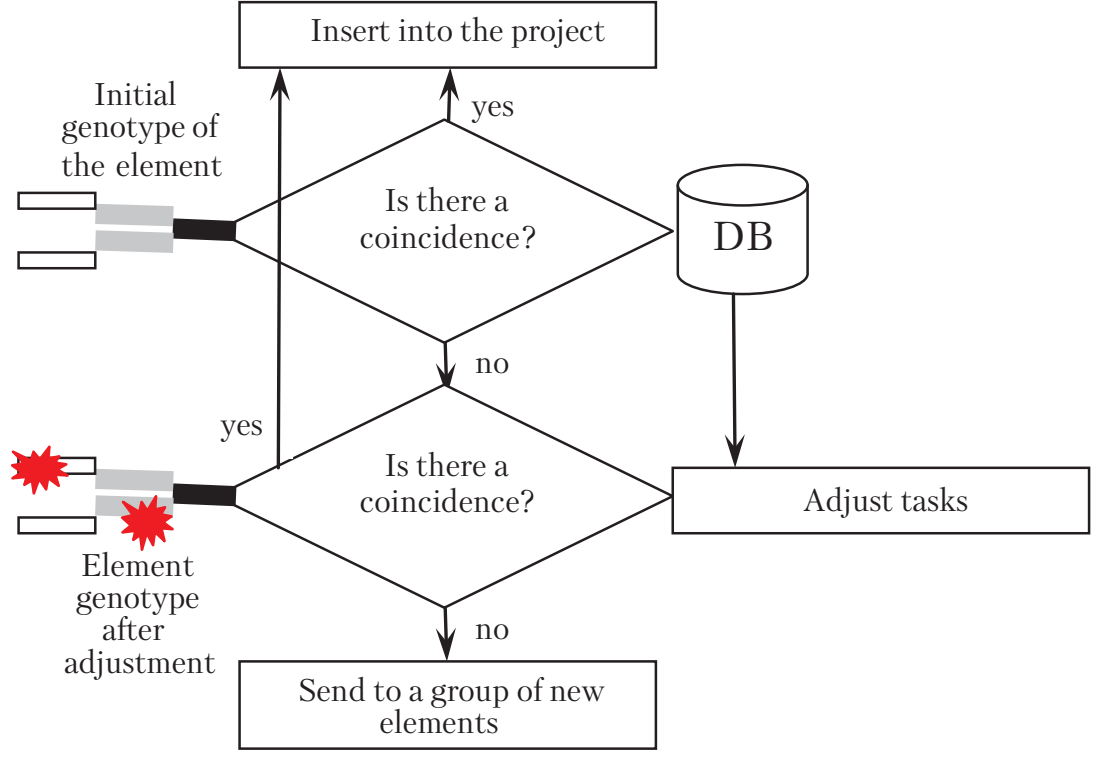

Fig. 8. The scheme of the algorithm for selecting purchased elements 
6.3. Practical use of research results. In «Geomoras» Ltd. (Odesa, Ukraine), a symbolic system for supporting design solutions developed at the Odessa National Polytechnic University was tested, as well as a reduction in the cost and duration of the «TEHED» projects. The structure of the symbolic CAD «TEHED» is shown in Fig. 9.

CAD «TEHED» was involved in reengineering (restoration) of the facade of an industrial facility in order to increase its ventilation, energy-saving and lighting characteristics. Tests show that the use of CAD «TEHED» allowed to achieve such technical and economic results:

- about the course of reengineering:

- the cost of installation works decreased by 1.3 times;

- the lease term for warehouses decreased by $18 \%$;
- the number of intermediate stages for the re-equipment of the working area of handling operations has decreased;

- the speed of information processing in the logistics department has increased by $7 \%$;

- on the quality of reengineering;

- the illumination of the most darkened areas of the premises increased by almost $40 \%$;

- total costs for heating the premises of the facility decreased $11.7 \%$ while maintaining the average temperature in the premises;

- the amount of carbon monoxide $\left(\mathrm{CO}_{2}\right)$ in the air of the internal volume of the building decreased by $27.1 \%$.

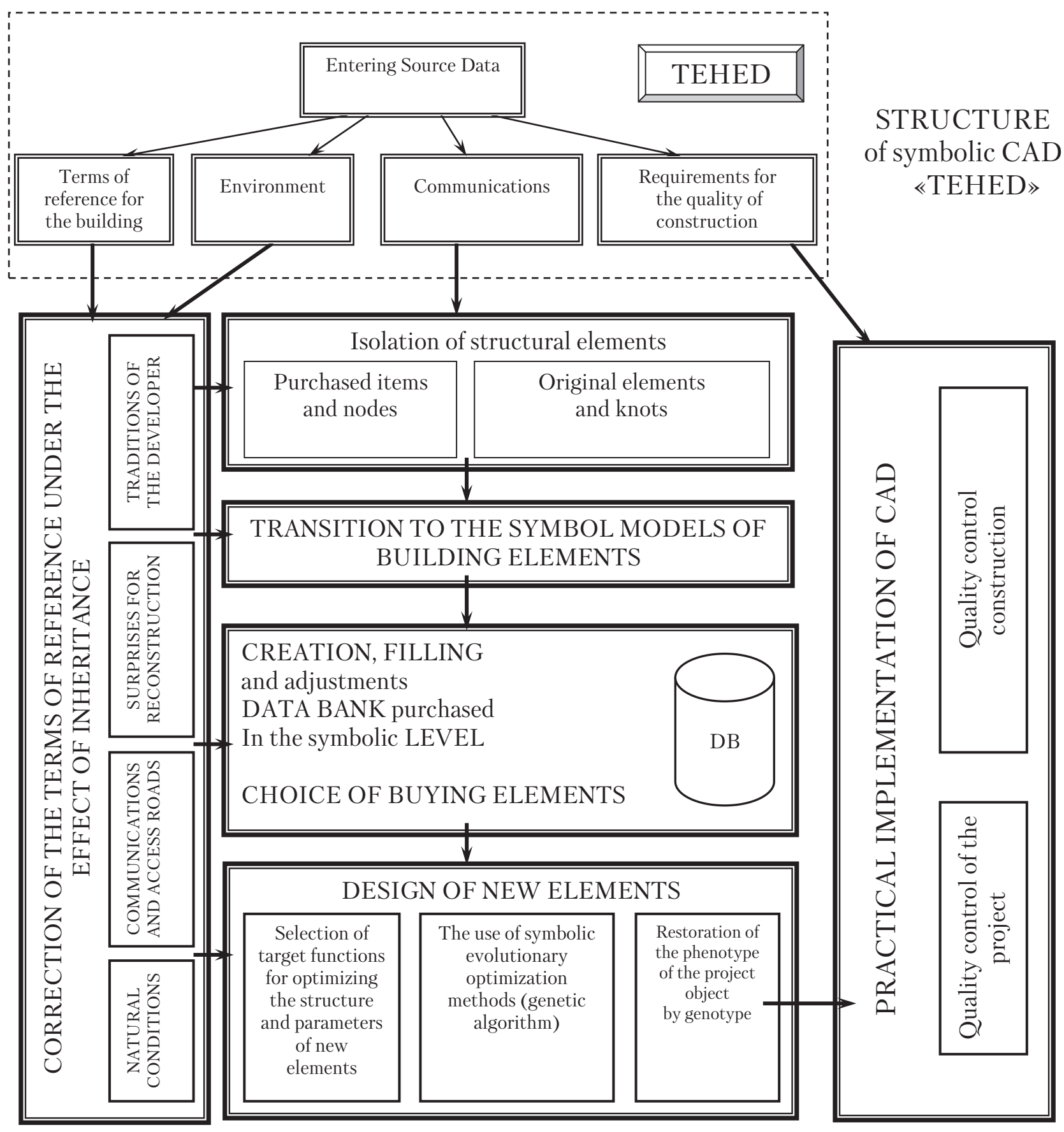

Fig. 9. Structure of the symbolic CAD «TEHED» 


\section{SWOT analysis of research results}

Strengths. The main positive influence of the research object on its internal factors is the opportunity created by it at the initial stages of designing to influence its main object - the symbolic model of the future building. This allows to significantly improve the efficiency of the main stages of CAD in general, in particular, the optimization of the construction of the building and its individual elements.

Weaknesses. The main negative influence of the research object on its internal factors is the need to represent all the characteristics of the object in the form of a symbolic two-valued chromosome, with a large number of parameters, looks very burdensome even for a computer.

Opportunities. Opportunities for further research in this area are related both to the development of the theoretical base and to the improvement of methods and means of improving the quality of construction through the creation of new symbolic models. These models «work» throughout the entire stage of individual design of building structures.

Threats. As in any case of individual design, the threat of this «activity» is a continuation of its main advantages: the design is carried out taking into account the adaptability of the technical assignment for construction. At the same time, the implementation of the proposed method will not lead to any additional costs in the construction industry. It is based on the application of new simple methods and models.

There are no complete analogues of the proposed models and methods in the design. Earlier, symbolic models were not used in the design of the building at the optimization stages.

\section{Conclusions}

1. As a result of the analysis of the role of the terms of reference and its place in the process of automated design of building structures, it is established that the initial task must be constantly adapted to the external and internal environment of the building. On the other hand, it must also adapt to the conditions that the particular building has inherited from its predecessors or neighbors.

2. It is proposed to use models known as the complex genetic algorithm in the form of branched chromosomes as symbolic models of building structures, and the accumulation of «same-sex mutations» in them to simulate ossification (prohibition of change) in any transformation of the corresponding genes.

3. The results of the work in the form of CAD «TEHED» are involved in the reconstruction of the facade of the industrial facility in order to increase its ventilation, energy-saving and lighting characteristics. The tests show that the use of CAD «TEHED» allows to reduce the terms of automated design of reconstruction by $23.4 \%$, as a result, the cost of reconstruction was $18.9 \%$ lower than planned.

\section{References}

1. Baranov, V. V. Tehnologicheskii audit predpriiatiia $\mathrm{v}$ semi shagah [Electronic resource] / V. V. Baranov // Elitarium. Available at: \www/URL: http://www.elitarium.ru/tekhnologicheskijj_audit_predprijatija/
2. Vasiliev, A. S. Tehnologicheskaia nasledstvennost' v mashinostroenii [Text] / A. S. Vasiliev // Vestnik Rybinskoi gosudarstvennoi aviatsionnoi tehnologicheskoi akademii im. P. A. Solovieva. 2017. - No. 1 (40). - P. 198-202.

3. Yashcheritsyn, P. I. Tehnologicheskoe nasledovanie ekspluatatsionnyh parametrov detalei mashin [Text] / P. I. Yashcheritsyn // Spravochnik, inzhenernyi zhurnal. - 2004. - No. 9. - P. 20-22.

4. Lapidus, V. A. Sovmestimy li standartizatsiia i tvorchestvo? [Text] / V. A. Lapidus, M. E. Serov // Metody menedzhmenta kachestva. - 2017. - No. 5. - P. 60-61.

5. Tsytsyliano, O. Kreatyvnist ta standartyzatsiia yak osnova konkurentospromozhnosti orhanizatsii [Text] / O. Tsytsyliano // Standartyzatsiia. Sertyfikatsiia. Yakist. - 2007. - No. 1 (44). P. $66-71$

6. Novikov, S. Svoei koleei [Text] / S. Novikov // Standarty i kachestvo. - 2007. - No. 8. - P. 34-35.

7. Istoriia razvitiia kolei [Electronic resource]. - Available at: \www/URL: http://rzd-expo.ru/history/Istoriya\%20razvitiya $\% 20$ kolei/

8. Jia, J. Mechanisms of drug combinations: interaction and network perspectives [Text] / J. Jia, F. Zhu, X. Ma, Z. W. Cao, Y. X. Li, Y. Z. Chen // Nature Reviews Drug Discovery. 2009. - Vol. 8, No. 2. - P. 111-128. doi:10.1038/nrd2683

9. Kolesnykova, K. The project management of the building structure reengineering by the limits in all functional areas [Text] / K. Kolesnykova, D. Monova, A. Toropenko, O. Toropenko, A. Sh. Ali // Technology Audit and Production Reserves. - 2016. - Vol. 5, No. 2 (31). - P. 18-23. doi:10.15587/ 2312-8372.2016.79982

10. Martin, J. N. T. Metaphors in Mind: Transformation Through Symbolic Modelling [Text] / J. N. T. Martin // Metaphor and Symbol. - 2007. - Vol. 22, No. 2. - P. 201-211. doi:10.1080/ 10926480701235510

11. Rees, J. The Use of Clean Language and Metaphor in Helping Clients Overcoming Procrastination [Text] / J. Rees, A. I. Manea // Journal of Experiential Psychotherapy. - 2016. - Vol. 19, No. 3. - P. 30-36.

12. Ferreira, C. Gene Expression Programming: A New Adaptive Algorithm for Solving Problems [Text] / C. Ferreira // Complex Systems. - 2001. - Vol. 13, No. 2. - P. 87-129.

13. Technical Drawing Specifications Resource. A guide to support VCE Visual Communication Design study design 2013-17 [Electronic resource]. - Available at: \www/URL: https:// www.slideshare.net/bhubanfomb/technical-drawing-specifications

14. Gogunskii, V. D. Upravlenie seriinymi proektami v mashinostroenii [Text] / V. D. Gogunskii, I. I. Stanovska, I. N. Guriev // Suchasni tekhnolohii v mashynobuduvanni. - 2013. - No. 8. P. 254-262.

15. Gogunskii, V. D. The complex optimization problems in the control of same objects creation program [Text] / V. D. Gogunskii, I. I. Stanovska, I. N. Guriev // Informatsiini tekhnolohii v osviti, nautsi ta vyrobnytstvi. - 2013 - No. 1 (2). P. 250-255.

16. Cui, W. Tupni: Automatic reverse engineering of input formats [Text] / W. Cui, M. Peinado, K. Chen, H. J. Wang, L. IrunBriz // ACM Proceedings of the 15th ACM Conference on Computer and Communications Security. - Virginia, 2008. P. 391-402. doi:10.1145/1455770.1455820

17. Chetverikov, G. G. Formal'noe opisanie logicheskogo prostranstva [Text] / G. G. Chetverikov, I. D. Vechirskaia // Shtuchnyi intelekt. - 2008. - No. 3. - P. 781-789.

18. Zhang, J. Clustering-Based Adaptive Crossover and Mutation Probabilities for Genetic Algorithms [Text] / J. Zhang, H. S.-H. Chung, W.-L. Lo // IEEE Transactions on Evolutionary Computation. - 2007. - Vol. 11, No. 3. - P. 326-335. doi:10.1109/tevc.2006.880727

19. Stanovskyi, O. Connectivity optimization of the elements in the tasks of computer-aided system design [Text] / O. Stanovskyi, P. Shvets, A. Toropenko, V. Bondarenko, Sh. O. Abu, O. Krasnozhon, A. Stanovskyi // Bulletin of The National Technical University «Kharkiv Polytechnic Institute»: MechanicalTechnological Systems And Complexes. - 2015. - Vol. 49. P. 170-175. - Available at: \www/URL: http://mtsc.khpi.edu.ua/ article/view/59969 


\section{РАЗРАБОТКА СИМВОЛЬНОГО ОБРАЗА СТРОИТЕЛЬНОГО} СООРУЖЕНИЯ В САПР

Показано, что автоматизированное строительное проектирование постоянно требует обновления модели сооружения Эта модель должна отражать не только первичное техническое задание на строение, но и выявленные при проектировании изменения и события в турбулентной внутренней и внешней окружающей будущее строительство среде. Предложена модель строительного сооружения в виде символьного образа комплексной генетической хромосомы и метод поддержки адекватности между ним и переменной средой.

Ключевые слова: строительное проектирование, обновление модели, турбулентная среда, символьный образ, техническая наследственность.

Stanovskyi Alexandr, Doctor of Technical Science, Professor, De partment of Oilgas and Chemical Mechanical Engineering, Odessa
National Polytechnic University, Ukraine, ORCID: http://orcid.org/ 0000-0002-0360-1173

Abu Shena Osama, Department of Oilgas and Chemical Mechanical Engineering, Odessa National Polytechnic University, Ukraine, e-mail: abu.shena@gmail.com,ORCID: https://orcid.org/0000-00032722-7638

Toropenko Oleksii, Department of Oilgas and Chemical Mechanical Engineering, Odessa National Polytechnic University, Ukraine, e-mail: alexey.toropenko@geomoras.net, ORCID: https://orcid.org/ 0000-0002-3699-4460

Daderko Olesya, Department of Oilgas and Chemical Mechanical Engineering, Odessa National Polytechnic University, Ukraine, e-mail: o.daderko@gmail.com,ORCID: https://orcid.org/0000-00030160-7288

\section{Antypenko Y., Ivko $A$.}

\section{ANALYSIS OF APPROACHES TO DEVELOP OF THE COMPETENTS SYSTEM OF THE PROJECT TEAM OF THE BUILDING COMPANY VIRTUAL LOGISTIC CENTER CREATION}

Поставлена задача розвитку компетентності проекту створення віртуального логістичного центру будівельної компанії. Досліджено підходи до ідентифікащії і розвитку індивідуальної i організаційної компетентності. Для проекту розглянуто наповнення 28-и компетенцій згідно з моделлю Міжнародної асоціації управління проектами. Запропонована комбінована модель розвитку організаційно-індивідуальних компетенцій.

Ключові слова: управління проектами, будівельна логістика, компетентність проекту, організаційно-індивідуальні компетенції.

\section{Introduction}

The trend in modern management has become the use of virtual organizational structures and virtual project teams. This trend is relevant for the construction sphere. More and more companies are thinking about minimizing the costs of maintaining offices and moving to the remote form of managing employees.

This approach is especially relevant in construction logistics. This construction specialization requires constant territorial dynamics of logistics, permanent and all-round contacts, including eye and personal contacts, including with stakeholders, territorially distributed in the space of a city or region.

In this sense, construction companies should consider the virtual approach as the basis for organizing teams and teams of construction logistics. To start such association, which can be called a virtual logistics center for construction, it is necessary to carry out activities that are of a project nature. Namely, to implement the pro- ject of creating a virtual logistics center of a construction company.

However, this project has certain risks associated with the issue of ensuring the necessary discipline of the virtual project team members, the performance of tasks assigned to them on time and qualitatively. This requires the formation of approaches to development of the competence system of the team of such project.

\section{The object of research and its technological audit}

The object of research is the system of competence of the team creating a virtual logistics center of a construction company.

Technological audit of the object reveals differences in the competence system for projects implemented in various fields of application (applied spheres). Along with the differences, in the systems of competences in different areas there are common features. So, the core of the 